\title{
Scatella (Neoscatella) alticola sp.n. - new species of shore-flies (Diptera: Ephydridae) from Indonesia
}

\author{
Scatella (Neoscatella) alticola sp.n. - новый вид мух-береговушек \\ (Diptera: Ephydridae) из Индонезии
}

\author{
M.G. Krivosheina ${ }^{1}$, A.L. Ozerov ${ }^{2}$ \\ М.Г. Кривошеина, А.А. Озеров
}

\begin{abstract}
${ }^{1}$ A.N. Severtsov Institute of Ecology and Evolution, Russian Academy of Sciences, 119071 Moscow, Russia. E-mail: dipteramarina@rambler.ru

${ }^{2}$ Zoological Museum, Lomonosov Moscow State University, Bol'shaya Nikitskaya 6, Moscow 125009, Russia. E-mail: ozerov2455@rambler.ru

${ }^{1}$ Институт проблем экологии и эволюции им. А.Н.Северцова РАН, Ленинский проспект, 33, Москва 119071, Россия. Е-таі1: dipteramarina@rambler.ru

23оологический музей, Московский государственный университет им. М.В. Ломоносова, Большая Никитская ул., 6, Москва 125009, Россия.
\end{abstract}

KEY WORDS: Diptera, Ephydridae, Scatella, Neoscatella, alticola sp.n., Indonesia, description, key.

КЛЮЧЕВЫЕ СЛОВА: Diptera, Ephydridae, Scatella, Neoscatella, alticola sp.n., Индонезия, описание, определительная таблица.

ABSTRACT. Scatella (Neoscatella) alticola sp.n., a new species from the family Ephydridae (Diptera) is described from Indonesia. Imagoes were collected at Habbema mountain at the height $3350 \mathrm{~m}$ near stream. The new species is close to $S$.(N.) vittithorax Malloch, 1925 , differing from it by body coloration and position of thoracic setae. A key to Australian and Indonesian species of subgenus Neoscatella is given.

PЕЗЮМЕ. Описан новый вид - Scatella (Neoscatella) alticola sp.n. мух-береговушек (Diptera, Ephydridae) из Индонезии. Имаго собраны на вершине горы Хаббема на высоте 3350 м вблизи ручья. Вид близок S.(N.) vittithorax Malloch, 1925, от которого отличается окраской тела и расположением грудных щетинок. Приводится определительная таблица автралийских и индонезийских видов подрода Neoscatella.

\section{Introduction}

The subgenus Neoscatella Malloch, 1933 of the genus Scatella Robineau-Desvoidy, 1830 now includes 36 valid species distributed mainly in Southern Hemisphere: 22 species are known from Australasian/Oceanian regions, 1 species is recorded from Afrotropical and 3 species - from Neotropical regions [Mathis, Zatwarnicki, 1995]. As for Nearctic and Palaearctic regions - 3 species only and 6 species are reported to be distributed there [Mathis, Zatwarnicki, 1995; Krivosheina, 2009]. Almost all of abovementioned species were described before 1982 year.
The group of Australasian/Oceanian species artificially can be divided in two parts: 11 species, which were described from Hawaiian Islands and never registered on other territories and 11 Australian/New Zealand species, which are endemic too as for their present distribution. Such pattern to our opinion doesn't reflect weak knowledge on the distribution or insufficient material from the region, for the repeated collecting allowed to confirm previous data only.

Taxonomic study of Hawaiian Ephydridae [Wirth, 1948] united the data on about 10 species. The revision of the Australian species of the subgenus Neoscatella [Mathis, Wirth, 1981] provided us detailed data on the distribution of 3 previously known and 6 newly described species. Large Diptera materials collected in Indonesia by N.Vikhrev and O. Eremenko allowed us to discover one more species of Neoscatella new to science.

Taxonomic part

Scatella (Neoscatella) alticola sp.n.

Figs. 1-5.

TYPE MATERIAL. Holotype $\sigma^{7}$, INDONESIA: W Papua, Habbema L., 3350m, 4.14S 138.71E, 19.XII.2014, N.Vikhrev. The Holotype is intact, glued to a pin, genitalia extracted so that epandrium, surstyli and gonites are visible laterally, in good condition. Paratypes: $8 \sigma^{7} \sigma^{7}, 3$ 우, the same label; $1 \sigma^{7}, 1$, INDONESIA: W Papua, Habbema L., 3350m, 4.14S 138.71E, 26.XII.2014, O.Eremenko. Four paratype male specimens with abdomen cut and dissected, genitalia preparated and put in glycerol tubes attached to the specimens; the rest specimens intact. The holotype and paratypes are deposited in the collection of the Zoological Museum, Moscow University. 
DIAGNOSIS. Specimens of these species are similar to S. vittithorax Malloch, 1925 and S. immaculata Malloch, 1925 by wing pattern, to $S$. vittithorax and $S$. norrisi Mathis et Wirth, 1981 — by large size and relative position of the fore pairs of acrostical and dorsocentral setae. The new species differs from $S$. vittithorax by the following combination of characters: distance between antennal bases equal to the width of the second antennal segment; facial coloration golden-brown; coloration of gena the same; scutum and scutellum brownblack, subshining; all coxae silvery-grey; femora, tibiae and tarsi black; wings darkened, with five light areas, light area of wing cell $\mathrm{R}_{3}$ not extending to the width of cell; costal vein index about $3: 1$; costal vein uniformly thickened and significantly stronger than vien $\mathrm{R}_{2+3}$.

DESCRIPTION. Small to moderately small shoreflies; length of male 1.5-2.1 mm, female - 2.1-2.5 $\mathrm{mm}$; mostly brown; partly pollinose, partly subshining.

Head. Face in profile moderately prominent, similar to S. immaculata [Mathis \& Wirth, 1981, Fig. 22]. Head width-to-height ratio averaging 1.2:1; frons pollinose to different extent, more pollinose anteriorly, on ocellar triangle and thinly pollinose, subshiny to shiny laterad from ocellar triangle; lateroclinate fronto-orbital setae strong, subequal in length and equal to ocellar and outer vertical setae. Antennae black, length of the third (apical) antennal segment exceeding combined length of segments 1-2; arista black. Distance between antennal bases equal to width of antennal segment 2 . Face golden-brown with four setae: the upper is directed downwardly and the three setae upcurved; the length of setae enlarging downwardly. Eyes oval and inclined to the plane of epistomal margin. Gena low; eye-tocheek ratio is about 5:1; genal coloration like coloration of face. Palpus black.

Thorax (Fig. 5). General coloration of scutum and scutellum mostly brown-black, subshining, but a little more pollen than frons. Pleural areas pollen, goldenbrown. The only anterior pair of relatively thick and long acrostical setae, three pairs of strong dorsocentral setae; anterior pair of acrostical setae is situated behind anterior pair of dorsocentral setae (Fig. 5). Coxae of all legs silvery-grey. Femora, tibiae and tarsi black. Wings of both sexes with five spots distinct in male and in female specimens (Fig. 4). Halter yellow.

Abdomen. Brown-black, sparsely pollen, subshiny, with lighter posterior margins on terga including fifth tergum. Tergite 5 two times as long as tegite 4. Epandrium in posterior view large, equal to tergite 5 in length, surstyli narrow and setose (Fig. 2). Surstyli curved outwardly (Fig. 1). Gonites narrow and pointed apically (Figs 1, 2). Sternites 2-5 covered with setae, sternite 5 divided in two parts (Fig. 3). Aedeagus broad, aedeagal apodeme of usual structure, similar to those of S. crassicosta Becker, 1896 [Olafsson, 1991, Fig. $18 \mathrm{f}]$.

ETYMOLOGY. The name "alticola" is given to this species because it was collected at the height $3350 \mathrm{~m}$.

DISTRIBUTION. Indonesia (West Papua).
Key to Australian and Indonesian SPecies of SCATELLA (NEOSCATELLA) (AFTER Mathis \& Wirth [1981] EXPANDED)

1. Mesofrons uniformly and densely pollinose, appearing dull ........................................................................... 2

- Mesofrons laterad of ocellar triangle thinly pollinose, appearing subshiny to shiny .............................................. 6

2. At least 2 pairs of conspicuous porrect to slightly upcurved larger facial setae between dorsum of interfoveal carina and postroventral corner of face ........................ 3

- Facial setae generally inconspicuous except for 1 pair of larger, porrect to slightly upcurved setae inserted near lateral margin of face ...

3. Pollinose vestiture of mesonotum generally grey except for brown stripe along acrostichal track; infuscation of wing darker, brownish, pattern of white spots distinctly contrasting; first section of costal vein thickened in male; white area of cell $\mathrm{R}_{3}$ of male wing reduced or lacking, if present, narrow and attenuated medially, appearing as 2 spots; front coxa and femur similar in both sexes ......... S. norrisi Mathis et Wirth, 1981 (in part)

- Pollinose vestiture of mesonotum unicolorous, grey to lightly yellowish grey; infuscation of wing pale, lightly tan, pattern of white spots inconspicuous; first section of costal vein not thickened in male; white area of cell $R_{3}$ of male wing large, subquadrate; anteroventral surface of front coxa and ventrobasal surface of front femur similar with conspicuous patch of longer setae in male ............ S. immaculata Malloch, 1925

4. Frons bicolored: mesofrons brown, parafrons lightly tannish white; face protruding far forward beyond antennae S. tasmaniae Mathis et Wirth, 1981

- Frons unicolorous; face not protruding far forward beyond antennae

5. Male face bicolored: dark brown below interfoveal carina and yellowish along oral margin; male wing dark brown at about apical two-thirds; costal vein of wing swollen; female with unicolorous face, wing veins of normal structure ............................ S. bicolor Mathis et Wirth, 1981

- Male face unicolorous, whitish; male wing infuscated apically, white spots large, costal vein thickened; female with whitish face, with small area just below carina lightly yellowish; wing veins of normal structure ......... S. albilutea Mathis et Wirth, 1981

6. Mesonotum mostly greyish except for a moderately broad longitudinal stripe along acrostichal track and 2 faint narrow stripes along dorsocentrals …………..... S. norrisi Mathis et Wirth, 1981 (in part)

- Mesonotum mostly brown to dark brown with some mostly anterior greyish areas ............................................... 7

7. Cell $R_{3}$ with 2 white spots, one aligned apical of posterior crossvein and the other in apical one-fourth of cell ...... S. victoria (Cresson, 1935)

- Cell $R_{3}$ with 1 white spot, aligned apical of posterior crossvein

8 . Wings of similar pattern in both sexes, with 5 relatively large white spots (Fig. 4) ........................................... 9

- Wings of different pattern in sexes, with more than 5 white spots of varying size

10

9. Costal index about 3:1, costal vein of male thickened, long acrostical setae situated behind the first pair of dorsocentral setae, coxae grey ............. S. alticola, sp.n.

- Costal index about 5:1, costal vein of male not thickened, long acrostical setae situated in one transverse row with the first pair of dorsocentral setae .....

S. vittithorax Malloch, 1925 

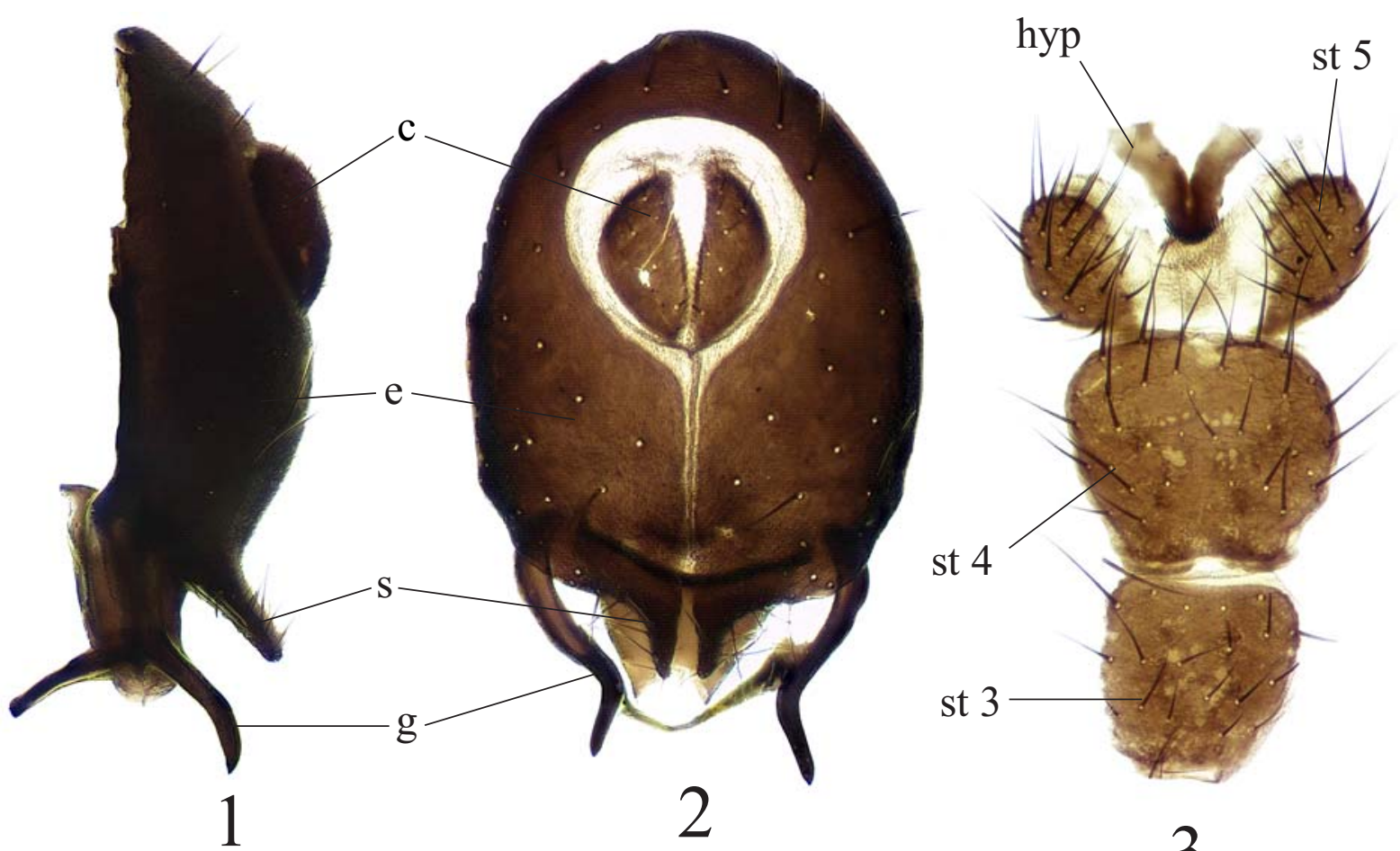

3
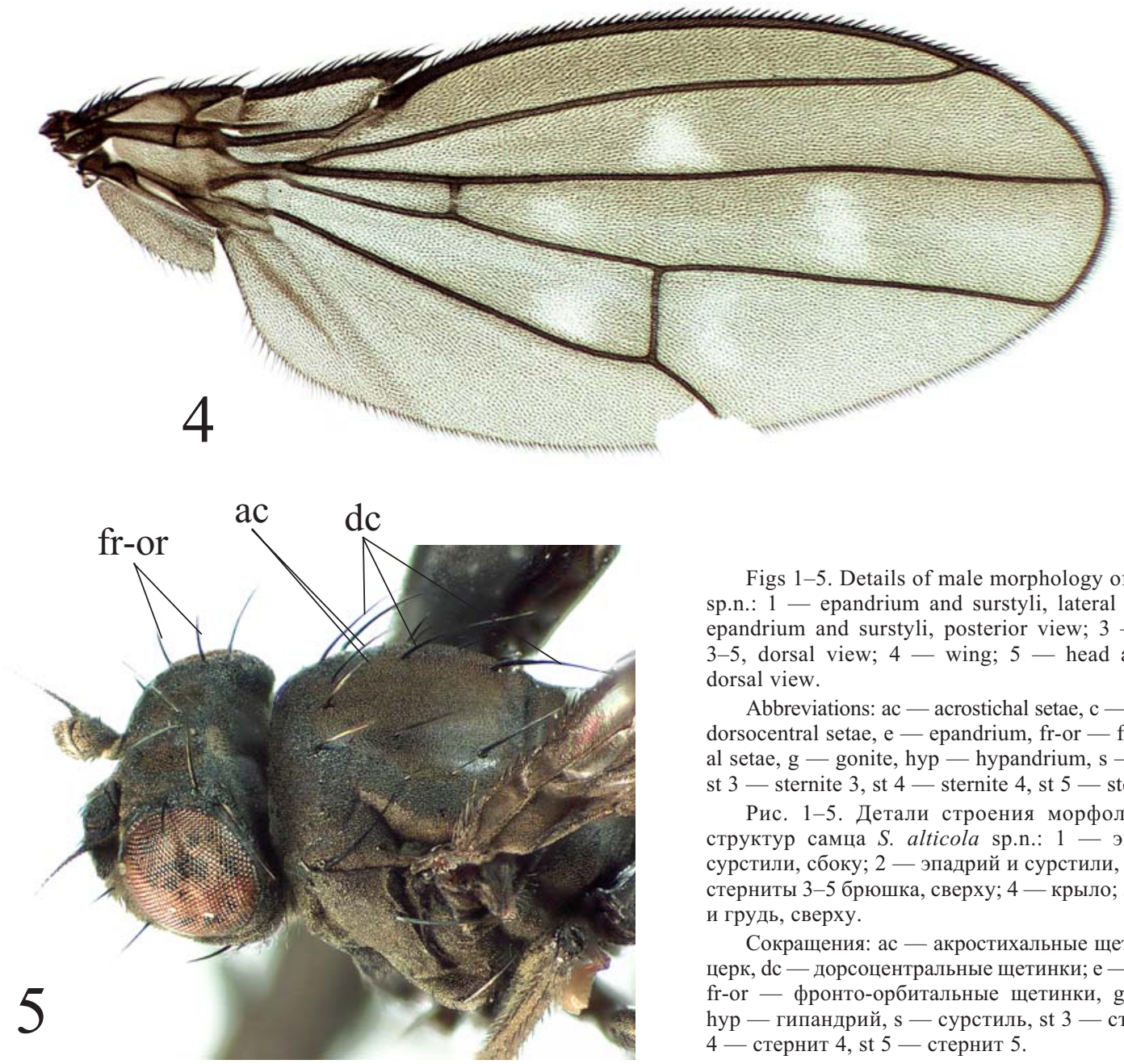

Figs 1-5. Details of male morphology of S. alticola sp.n.: 1 - epandrium and surstyli, lateral view; $2-$ epandrium and surstyli, posterior view; 3 - sternites 3-5, dorsal view; $4-$ wing; 5 - head and thorax, dorsal view.

Abbreviations: ac - acrostichal setae, $\mathrm{c}$ - cerc, $\mathrm{dc}-$ dorsocentral setae, e - epandrium, fr-or - fronto-orbital setae, g - gonite, hyp - hypandrium, s - surstylus, st 3 - sternite 3 , st 4 - sternite 4 , st 5 - sternite 5 .

Рис. 1-5. Детали строения морфологических структур самца $S$. alticola sp.n.: 1 - эпандрий и сурстили, сбоку; 2 - эпадрий и сурстили, сзади; 3 стерниты 3-5 брюшка, сверху; 4 - крыло; 5 - голова и грудь, сверху.

Сокращения: ac - акростихальные щетинки; с церк, $\mathrm{dc}$ - дорсоцентральные щетинки; е - эпандрий, fr-or - фронто-орбитальные щетинки, g - гонит, hyp - гипандрий, s - сурстиль, st 3 - стернит 3 , st 4 - стернит 4 , st 5 - стернит 5 . 
10. Wing with 2 subapical white spots in cell $\mathrm{R}_{5}$ aligned almost perpendicularly to longitudinal veins; female wing sometimes with a pale spot at base of cell $\mathrm{R}_{1}$; male specimens with oral setae denser and longer, especially toward median ........ S. insularis Mathis et Wirth, 1981

- Wing with 2 subapical sometimes fused white spots in cell $\mathrm{R}_{5}$ aligned markedly obliquely to longitudinal veins; female wing without a pale spot at base of cell $\mathrm{R}_{1}$; oral setae in male similar to female

$$
\text { S. austrina Mathis et Wirth, } 1981
$$

DISCUSSION. Mathis \& Wirth [1981] separated 3 species-groups inside the subgenus Neoscatella for Australian species: bicolor, including 3 species, immacula$t a$, including 2 species and austrina. The last species group include 4 species: Scatella (N.) austrina, S.(N.) vittithorax, $S$.(N.) victoria and $S$.(N.) insularis. The main characters for this species-group were as following. Generally pollinose species with extensive areas sparsely pollinose to bare; frons pollinose except around ocellar triangle, especially laterad apprearing bare and shiny; at least 2 facial setae evident, with 3-4 large porrect facial setae; tarsi mostly concolorous with tibiae, blackish; fused surstyli and ventral margin of epandrium setose. The new species corresponds completely to these characters and enlarges this group to 5 species.

The biology of all representatives of the genus $\mathrm{Sca}$ tella is typical in general for Ephydridae. Adults are common in wet habitats including moist soil and algae at river banks, near lakes, ponds, pools, ditches [Thier, Foote, 1980]. Some species are more restricted to sea coasts [Brauns, 1939] or found in thermal springs [Tuxen, 1936]. Larvae as a rule develop in same ecosystems often among larvae of other ephydrid species [Krivosheina, 1987], feeding mainly on algae and cyanobacteria [Zack, Foote, 1978; Krivosheina, 2008]. Some species have extremely high rate of population growth which may be connected with reproductive adaptations to different types of habitats, both unstable and ephemeral and stable and long lasting [Connell, Scheiring, 1982]. There are no special works devoted to biology of Australasian/Oceanian Scatella however soma data are available from material labels. Specimens of Hawaiian species Neoscatella warreni Cresson, 1926 were captured on moist rocks in stream bed, swift water ditches, on wet boulders; $N$. cilipes Wirth, 1948 and $N$. hawaiiensis Grimshaw, 1901 — in bogs at summit $4000 \mathrm{ft}$, edges of swift water, on wet rocks of stream margin [Wirth, 1948]. N. immaculata was registered near water hole, $N$. austrina - at inlet near sandbar, N. albilutea was captured at estuary [Mathis, Wirth, 1981]. Some species - N. bryani Cresson, 1926 and $N$. sexnotata Cresson, 1926 are known to be attracted to light traps. The latter species was also discovered in salt habitats - marshy bay shore, rocks by sea, stranded seaweed on beach [Wirth, 1948]. The close habitat, ocean beach, is known for $N$. tasmaniae [Mathis, Wirth, 1981]. The specimens of the new species were collected at grass-schrub basin of Habbema lake on sand soil, which was well washed because of often rains and of white color. The flies rested near springs on this pure sand or were slipping on water surface.

ACKNOWLEDGEMENTS. The authors are very grateful to Dr. Nikita Vikhrev and Mrs Oksana Eremenko who organized the field trip to Indonesia, collected and handed over for examination such valuable materials on Diptera.

The reported study was supported by RSF, research project No.14-50-00029.

\section{References}

Brauns A. 1939. Zur Biologie der Meersstrandfliege Scatella subguttata Meig. (Familie Ephydridae: Diptera)// Zoologischer Anzeiger. Bd.126. H.11/12. S.273-285.

Connell T.D., Scheiring J.F. 1982. Demography of the shore fly Scatella picea (Walker) (Diptera: Ephydridae) // Environmental Entomology. Vol.11. No.3. P.611-617.

Krivosheina M.G. 1987. [On the biology of Parydra aquila Fll. (Diptera, Ephydridae)] // Entomologicheskoe Obozrenie. Vol.66. No.3. P.540-542 [in Russian].

Krivosheina M.G. 2008. On Insect feeding on cyanobacteria // Paleontological Journal. Vol.42. No.6. P.596-599.

Krivosheina M.G. 2009. [On the distribution of the shore-fly Scatella crassicosta Becker, 1896 (Diptera, Ephydridae) in the Far East of Russia] // Euroasian Entomological Journal. Vol.8. No.1. P.115-116 [in Russian].

Mathis W.N., Wirth W.W. 1981. Studies of Ephydrinae (Diptera: Ephydridae), IV: Revision of the Australian species of subgenus Neoscatella Malloch // Smithsonian Contributions to Zoology. No.325. 27 pp.

Mathis W.N., Zatwarnicki T. 1995. A world catalog of the shore flies (Diptera: Ephydridae) // Memoirs on Entomology, International. Vol.4. P.1-423.

Olafsson E. 1991. Taxonomic revision of western Palaearctic species of the genera Scatella R.-D. and Lamproscatella Hendel, and studies on their phylogenetic positions within the subfamily Ephydrinae (Diptera, Ephydridae) // Entomologica Scandinavica. Supplement 37. P.1-100.

Thier R.W., Foote B.A. 1980. Biology of mud-shore Ephydridae (Diptera) // Proceedings of the Entomological Society of Washington. Vol.82. No.4. P.517-535.

Tuxen S.L. 1936. Die Arten der Gattung Scatella (Ephydridae) in heissen Quellen // Opuscula Entomologica. Vol.1. No.4. P.105111.

Wirth W.W. 1948. A taxonomic study of Hawaiian Ephydridae (Diptera) related to Scatella Robineau-Desvoidy // Proceedings of the Hawaiian Entomological Society. Vol.13. No.2. P.277-304.

Zack R.S., Foote B.A. 1978. Utilization of algal monocultures by larvae of Scatella stagnalis // Environmental Entomology. Vol.7. No.4. P.509-511. 